p-ISSN: 2655-7304

e-ISSN: 6655-8953

\title{
Ketahanan Nasional Berbasis Ketahanan Keluarga pada Masa Pandemic Covid-19 di Kabupaten Bandung
}

\author{
${ }^{1}$ Rofi’ Ramadhona Iyoega, ${ }^{2}$ Rike Anggun Artisa, ${ }^{3}$ Cintantya Andhita Dara Kirana \\ Politeknik STIA LAN Bandung \\ J1. Hayam Wuruk No.34-38, Citarum, Kec. Bandung Wetan, Kota Bandung, Jawa Barat 40115 \\ ${ }^{1}$ rofi.r.iyoega@gmail.com \\ ${ }^{2}$ rikeanggunartisa@gmail.com \\ ${ }^{3}$ ca.darakirana@gmail.com
}

\begin{abstract}
National resilience will only be realized when supported by stability at the layer below it, namely local/regional resilience. Local/regional resilience is also impossible to create without strength at the family (self/individual) level. The Covid-19 pandemic can threaten the national security of the Indonesian nation. Therefore, the role of the family as a supporting pillar of national resilience must be increased. As the smallest social unit in society, the family has the responsibility to create a superior and competitive next generation, to educate the nation's children who have a balanced intelligence between intellectual, moral, and spiritual. This paper intends to explain the condition of family resilience during the Covid-19 pandemic and explain the contribution of families in realizing community resilience, which impacts the nation's national stability. The data collected in this research was conducted by interviewing and distributing questionnaires to respondents. A qualitative approach was chosen in this study through a study of the relevant literature.
\end{abstract}

Key Words: National Resilience, Family Resilience, Covid-19 Pandemic

\begin{abstract}
ABSTRAK
Ketahanan nasional (national resilience) baru akan terwujud ketika ditopang oleh ketahanan pada lapisan dibawahnya yakni ketahanan regional/wilayah. Ketahanan regional/wilayah juga mustahil tercipta jika tidak adanya ketahanan pada level keluarga (diri/individu). Pandemic Covid-19 berpotensi mengancam ketahanan nasional bangsa Indonesia. Oleh karenanya keluarga sebagai pilar penyokong ketahanan nasional harus ditingkatkan peranannya. Keluarga sebagai unit sosial terkecil dalam masyarakat memiliki tanggung jawab dalam mencetak generasi penerus yang unggul dan berdaya saing, mendidik anak bangsa yang memiliki kecerdasan yang berimbang antara intelektual, moral, dan juga spiritual. Tulisan ini bermaksud menerangkan kondisi ketahanan keluarga pada masa Pandemic Covid19 serta menjelaskan kontribusi keluarga dalam mewujudkan ketahanan masyarakat yang berdampak terhadap menguatnya ketahanan nasional bangsa. Pengumpulan data dalam penelitian ini dilakukan dengan metode wawancara (interview) dan penyebaran kuesioner kepada responden. Pendekatan kualitatif dipilih dalam kajian ini melalui studi pustaka yang relevan.
\end{abstract}

Kata Kunci: Ketahanan Nasional, Ketahanan Keluarga, Pandemic Covid-19

\section{PENDAHULUAN}

Ketahanan nasional (national resilience) sebagai salah satu konsepsi bernegara ditujukan untuk memperkuat kemampuan bangsa dalam mempertahankan persatuan dan kesatuannya dari segala bentuk ancaman dengan mengupayakan sumber daya yang ada agar terpenuhi kebutuhan hidupnya. Sebagai sebuah konsep, untuk mewujudkan ketahanan di tingkat nasional harus ditopang oleh ketahanan di level yang ada dibawahnya yaitu ketahanan regional/wilayah. Dan untuk mencapai ketahanan regional/wilayah terlebih dahulu harus dapat tercipta ketahanan keluarga atau ketahanan diri/individu [7].

Konsep ketahanan dan kesejahteraan keluarga dalam Undang-Undang Nomor 52 Tahun 2009 tentang Perkembangan Kependudukan dan Pembangunan Keluarga, digambarkan sebagai kondisi keluarga yang memiliki keuletan dan ketangguhan serta mengandung kemampuan fisik materil guna 
hidup mandiri dan mengembangkan diri dan keluarganya untuk hidup harmonis dalam meningkatkan kesejahteraan dan kebahagiaan lahir dan batin [10]. Konsep ketahanan dan kesejahteraan keluarga juga dapat ditemukan dalam Peraturan Menteri PPPA Nomor 6 Tahun 2013 tentang Pelaksanaan Pembangunan Keluarga. Ketahanan dan kesejahteraan keluarga dalam permen tersebut mencakup: (1) Landasan Legalitas dan Keutuhan Keluarga, (2) Ketahanan Fisik, (3) Ketahanan Ekonomi, (4) Ketahanan Sosial Psikologi, dan (5) Ketahanan Sosial Budaya [5].

Keluarga dikatakan memiliki tingkat ketahanan keluarga yang tinggi apabila memenuhi beberapa aspek yaitu: 1) ketahanan fisik yaitu terpenuhinya kebutuhan pangan, sandang, perumahan, pendidikan dan kesehatan; 2) ketahanan sosial yaitu berorientasi pada nilai agama, komunikasi yang efektif, dan komitmen keluarga tinggi; 3) ketahanan psikologis meliputi kemampuan penanggulangan masalah nonfisik, pengendalian emosi secara positif, konsep diri positif, dan kepedulian suami terhadap istri.

Mewabahnya pandemic Covid-19 di akhir tahun 2019 membuat gaduh hampir seluruh masyarakat dunia karena penyebarannya yang begitu cepat dan angka kematian yang memprihatinkan. Indonesia termasuk negara yang terkonfirmasi terdampak dari virus tersebut dengan jumlah korban yang makin hari kian meningkat. Mewabahnya pandemic Covid-19 ini telah mengharuskan masyarakat melakukan upaya-upaya agar dapat bertahan, maka dari itu berbagai upaya dilakukan agar dapat terhindar dari bahaya yang diakibatkan oleh virus tersebut.

Pandemic covid-19 nyatanya saat ini telah mengubah banyak sekali aspek dalam kehidupan masyarakat. Dimulai dari ruang gerak yang sudah dibatasi untuk menghindari penularan virus, di Indonesia sendiri sudah ada beberapa daerah yang memberlakukan sistem Pembatasan Sosial Berskala Besar (PSBB). Mewabahnya virus ini juga telah berdampak pada sektor ekonomi dimana dunia usaha tidak lagi dapat bertahan dengan kondisi tersebut sehingga mengakibatkan terjadinya pemutusan hubungan kerja secara besar-besaran. Selain itu, banyak sekali sektor informal dan UMKM terganggu akibat berbagai perubahan kondisi yang terjadi karena covid-19 ini.

Pandemic covid-19 ini juga telah mengubah berbagai macam pola dalam kehidupan masyarakat. Dari mulai anak yang sedang menempuh pendidikan yang kini harus menjalani pembelajaran dengan metode jarak jauh, jenis-jenis pekerjaan tertentu juga telah beralih dengan menggunakan teknologi informasi. Saat ini juga masyarakat didorong untuk membiasakan pola hidup bersih dengan selalu mencuci tangan dan menggunakan masker apabila keluar rumah. Perubahan-perubahan ini lah yang kemudian kita kenal dengan "New Normal Era" dimana hal yang semula dianggap tidak biasa menjadi hal yang biasa/normal untuk dilakukan.

Adanya berbagai perubahan yang terjadi akibat pandemic covid-19 ini selanjutnya menimbulkan sebuah permasalahan di masyarakat. Terjadi fenomena kerenatanan keluarga yang merujuk pada sebuah kondisi tertentu yang dapat mempengaruhi daya kemampuan keluarga dalam menghadapi permasalahan dan gangguan dalam menjalankan fungsinya. Kerentanan keluarga ini menjadi masalah yang kian besar mengingat tidak semua keluarga berada dalam kondisi yang siap dan mampu bertahan dengan perubahan-perubahan yang terjadi akibat mewabahnya virus tersebut.

Kondisi kerentanan keluarga ini jika kita lihat fenomenanya di Kabupaten Bandung telah berdampak pada sendi-sendi kehidupan masyarakat dimana saat ini tumbuh masyarakat miskin baru karena daya kemampuan keluarga tersebut cukup rendah dalam menghadapi perubahan situasi ini. Hal tersebut diantaranya ditenggarai oleh maraknya perusahaan di Kabupaten Bandung yang merugi dan banyak pekerja yang dirumahkan bahkan dipecat [6]. Selain itu, omzet dari pelaku ekonomi (UKM) di Kabupaten Bandung juga turun drastis [3]. Kondisi kerentanan ini kemudian menimbulkan dampakdampak turunan misalnya meningkatnya kasus kejahatan jalanan. Hal lain yang cukup menarik untuk dicermati adalah meningkatnya laporan kasus Kekerasan Dalam Rumah Tangga (KDRT) ke Polresta Kabupaten Bandung. Kondisi lain yang terjadi di Kabupaten Bandung diketahui bahwa curah hujan masih cukup tinggi sehingga menyebabkan beberapa titik tergenang dan terjadi banjir. Hal tersebut tentu memperparah sebagian kondisi masyarakat di tengah pandemic ini. Dampak dari fenomena diatas seperti gunung es dimana tentu banyak dampak lain yang tidak terlihat yang mempengaruhi kehidupan masyarakat.

Ketahanan keluarga menjadi sebuah isu yang penting dewasa ini dimana perubahan bisa terjadi kapan saja dalam waktu yang cepat. Ketahanan keluarga merujuk pada sebuah kondisi dimana kondisi keluarga yang dapat bertahan dan melakukan penyesuaian sehingga memiliki kemampuan dalam menghadapi permasalahan dan gangguan lainnya. Ketahanan keluarga ini merupakan isu yang cukup penting sebagai pondasi ketahanan nasional. Dengan demikian, menjadi sebuah tantangan untuk 
mewujudkan keluarga yang kokoh dan memiliki daya tahan yang baik.

Yudiyanto [14] melakukan penelitian tentang peran penting keluarga dalam mewujudkan ketahanan nasional. Hasil penelitiannya menunjukkan bahwa keluarga memiliki peran yang signifikan dalam mencetak generasi penerus bangsa yang berkarakter dan bermoral. Ini adalah modal dasar yang diperlukan, keluarga yang tangguh akan melahirkan masyarakat yang tangguh pula sehingga dapat tercipta bangsa yang memiliki ketahanan dalam pergaulan regional Masyarakat Ekonomi ASEAN atau MEA.

Berdasarkan penjabaran yang telah dikemukakan, penulis merasa tertarik melakukan penelitian tentang Ketahanan Nasional Berbasis Ketahanan Keluarga pada Masa Pandemic Covid-19 di Kabupaten Bandung. Penelitian yang dilakukan Yudiyanto [14] melihat peran keluarga dalam konteks MEA, berbeda dengan penulis yang ingin mendalami dalam konteks Pandemi Covid-19. Selain itu, penelitian ini juga ditujukan untuk mengetahui kondisi ketahanan keluarga dari berbagai aspek diantaranya legalitas dan keutuhan keluarga, ketahanan fisik, ketahanan ekonomi keluarga, ketahanan sosial psikologi keluarga, serta untuk mengetahui kondisi ketahanan sosial budaya keluarga di Kabupaten Bandung.

\section{KAJIAN PUSTAKA}

Ketahanan nasional (national resilience) menunjukkan ketahanan sebuah bangsa dalam mempertahankan persatuan dan kesatuannya. Ketahanan nasional dapat dilihat dalam tiga perspektif yakni ketahanan nasional sebagai sebuah kondisi, ketahanan nasional sebagai sebuah pendekatan dan strategi/metode, serta ketahanan nasional sebagai doktrin atau konsepsi. Sebagai sebuah kondisi, ketahanan nasional memberikan gambaran terhadap suatu keadaan yang seharusnya dipenuhi, keadaan ini memungkinkan suatu negara memiliki kemampuan mengembangkan kekuatan nasional sehingga mampu mengehadapi segala macam ancaman dan gangguan bagi kelangsungan hidup bangsa. Dalam perspektif kedua, ketahanan nasional dimaknai sebagai sebuah pendekatan yang mencerminkan segala aspek baik pada saat membangun maupun pemecahan masalah kehidupan. Adapun ketahanan nasional sebagai sebuah doktrin merupakan salah satu konsepsi khas Indonesia yang berupa ajaran konseptual tentang pengaturan bernegara, yaitu upaya menata hubungan antara aspek kesejahteraan dan keamanan dalam arti luas [7].

Ketahanan nasional sebagai sebuah konsepsi kehidupan berbangsa dan bernegara mencakup banyak aspek dalam kehidupan, mulai dari bidang politik, sosial, ekonomi, budaya serta pertahanan dan keamanan. Selain itu konsep ketahanan nasional juga dapat bermakna berlapis artinya ketahanan nasional sebagai kondisi yang kokoh dan tangguh dari sebuah bangsa tidak mungkin terwujud jika tidak dimulai dari ketahanan pada lapisan-lapisan di bawahnya. Untuk mewujudkan ketahanan di tingkat nasional (ketahanan nasional) harus ditopang oleh ketahanan di level yang ada dibawahnya yaitu ketahanan regional/wilayah, dan untuk mencapai ketahanan regional/wilayah terlebih dahulu harus dapat tercipta ketahanan keluarga atau ketahanan diri/individu.

Keluarga menjadi sebuah komponen penting di dalam masyarakat sebagai tempat individu membentuk kelompok terkecilnya. Keluarga merupakan sebuah konsep yang memiliki pengertian dan cakupan yang luas dan beragam. Keluarga, dalam konteks sosiologi, dianggap sebagai suatu institusi sosial yang sekaligus menjadi suatu sistem sosial yang ada di setiap kebudayaan [2]. Sementara itu menurut UU No. 52 Tahun 2009 Tentang Perkembangan Kependudukan dan Pembangunan Keluarga, Keluarga didefinisikan sebagai unit sosial terkecil dalam masyarakat yang terdiri dari: (1) suami dan istri; (2) suami, istri dan anaknya; (3) ayah dan anaknya; atau (4) ibu dan anaknya. Sebagai unit sosial terkecil di dalam masyarakat, keluarga dituntut kemampuannya untuk mampu menjadi komponen pertahanan pertama dalam menghadapi berbagai gangguan dan permasalahan akibat berbagai perubahan yang terjadi [10].

Adanya persoalan dalam kehidupan keluarga sebagai akibat adanya dinamika perubahan sosial, politik, ekonomi, budaya, dan lain-lain menjadi sebuah tantangan bagi ketahanan keluarga. Ketahanan keluarga menurut Frankenberger dalam Kemen PPPA [2] merupakan kondisi kecukupan dan kesinambungan akses terhadap pendapatan dan sumber daya untuk memenuhi berbagai kebutuhan dasar antara lain: pangan, air bersih, pelayanan kesehatan, kesempatan pendidikan, perumahan, waktu untuk berpartisipasi di masyarakat, dan integrasi sosial. Selain itu menurut Sunarti dalam DP3AKB Jabar [1] ketahanan keluarga adalah kemampuan keluarga untuk mengelola sumber daya dan masalah yang 
p-ISSN: $2655-7304$

e-ISSN: $6655-8953$

dihadapi keluarga agar keluarga sejahtera yaitu terpenuhinya kebutuhan seluruh anggota keluarga. Dengan demikian, ketahanan keluarga ini merujuk pada sebuah kondisi keluarga yang mampu memenuhi berbagai kebutuhan dasar dan mampu menghadapi segala permasalahan untuk menuju keluarga yang sejahtera baik secara lahir maupun batinnya.

Ketahanan keluarga menjadi hal yang penting untuk dipenuhi karena keluarga menjadi pondasi untuk menelurkan SDM yang unggul. Selain itu, keluarga yang memiliki ketahanan yang baik akan dapat menjalankan peran dan fungsinya dengan baik di masyarakat. Selain itu, ketahanan keluarga juga dapat mencegah masalah sosial dan ekonomi yang terjadi akibat kegagalan atau ketidakberfungsian keluarga. Sebuah keluarga dikatakan memiliki tingkat ketahanan keluarga yang tinggi apabila memenuhi beberapa aspek [2] yaitu:

1. Ketahanan fisik yaitu terpenuhinya kebutuhan pangan, sandang, perumahan, pendidikan dan kesehatan (melalui pemenuhan sumber daya ekonomi);

2. Ketahanan sosial yaitu berorientasi pada nilai agama, komunikasi yang efektif, dan komitmen keluarga tinggi;

3. Ketahanan psikologis meliputi kemampuan penanggulangan masalah nonfisik, pengendalian emosi secara positif, konsep diri positif, dan kepedulian suami terhadap istri.

Seperti yang telah diungkapkan sebelumnya bahwa penting untuk mewujudkan ketahanan keluarga. Berikut ini adalah dampak-dampak positif bagi keluarga yang memiliki ketahanan keluarga [1]:

1. Keluarga berpeluang besar untuk mencapai tujuan yang ingin dicapai yaitu keuarga yang bahagia, harmonis, sejahtera bahkan berkualitas;

2. Keluarga lebih mudah (tidak menghadapi kesulitan berarti) dalam menghadapi kondisi atau situasi darurat;

3. Keluarga akan lebih mudah beradaptasi terhadap berbagai perubahan situasi dan kondisi, khususnya yang tidak diinginkan;

4. Keluarga berkontribusi melahirkan SDM yang baik, generasi penerus bangsa yang menjadi sasaran pembangunan nasional;

5. Keluarga memilki kesempatan yang besar untuk berkontribusi dalam membangun lingkungan sosial yang sehat dan harmonis;

6. Keluarga berkontribusi dalam pembangunan bangsa dan negara.

\section{METODE PENELITIAN}

Pendekatan penelitian yang digunakan adalah dengan metode kualitatif. Penelitian ini berupaya mengukur tingkat ketahanan keluarga kemudian memahami secara mendalam tentang ketahanan keluarga di masa pandemic Covid-19 di Kabupaten Bandung. Fenomena mewabahnya pandemic Covid-19 ini telah menimbulkan adanya kerentanan keluarga. Tidak semua keluarga berada dalam kondisi yang siap dan mampu bertahan terhadap perubahan-perubahan yang terjadi akibat mewabahnya virus tersebut. Penelitian ini diarahkan untuk mengukur sejauhmana tingkat ketahanan yang dimiliki oleh keluarga serta peran keluarga dalam meningkatkan daya tahan mereka sehingga akan terbentuk ketahanan di level masyarakat dan secara lebih luas ketahanan nasional akan mudah dicapai.

Penelitian ini dilakukan di Kabupaten Bandung dengan mengambil sampel dari tiga kecamatan yang ditentukan secara purposive sampling yaitu Kecamatan Soreang, Kecamatan Bojongsoang, dan Kecamatan Kutawaringin. Jenis data yang digunakan adalah data primer dan data sekunder. Data primer merupakan data yang diperoleh langsung dari objek yang akan diteliti, sedangkan data sekunder adalah data yang diperoleh dari lembaga atau institusi tertentu [12]. Data primer dalam penelitian ini diperoleh melalui kuesioner yang dibagikan kepada masyarakat terdampak covid-19 untuk mengukur tingkat ketahanan keluarga. Setelah itu, untuk memperdalam hasil penelitian maka dilakukan wawancara kepada informan. Adapun data sekunder diperoleh dari dokumen-dokumen tertulis yang berkaitan dengan penelitian, misalnya berbagai peraturan perundang-undangan terkait dengan ketahanan keluarga.

Teknik pengumpulan data yang digunakan diantaranya melalui penyebaran kuesioner, kuesioner disusun merujuk indikator-indikator yang digunakan untuk mengukur tingkat ketahanan keluarga. Dalam penelitian ini peneliti juga melakukan wawancara dengan menggunakan metode wawancara semi terstruktur. Terlebih dahulu peneliti membuat pertanyaan berdasarkan keingintahuan dan 
kebutuhan peneliti. Untuk mendapatkan hasil wawancara yang yang optimal, perekaman terhadap wawancara pun dilakukan dan kemudian dibuat transkripnya. Teknik lain yang digunakan untuk mengumpulkan data adalah dengan dokumentasi. Data dari dokumen-dokumen yang relevan dijadikan sumber referensi pendukung untuk melengkapi data dan informasi yang kemudian dilakukan analisis.

Setelah informasi terkumpul serta dinyatakan cukup dan sesuai dengan kebutuhan, langkah selanjutnya adalah melakukan pengolahan data. Tahap awal yaitu melalui tindakan editing terhadap seluruh data yang diterima, peneliti memastikan kelengkapan kuesioner serta relevansi jawaban dari responden terhadap pertanyaan yang diajukan. Kemudian dilakukan pengklasifikasian dari jawaban yang diberikan oleh responden untuk memudahkan analisa. Langkah ini disebut sebagai coding. Barulah selanjutnya selanjutnya data dianalisis dan membuat kesimpulan [12].

\section{HASIL DAN PEMBAHASAN}

Sebagaimana tercantum dalam Undang-Undang Dasar 1945 pasal 28B ayat 1 disebutkan bahwa setiap orang berhak membentuk keluarga dan melanjutkan keturunan melalui perkawinan yang sah. Dalam Undang-undang No. 52 Tahun 2009 tentang Perkembangan Penduduk dan Pembangunan Keluarga menyebutkan bahwa pembangunan keluarga bertujuan meningkatkan kualitas keluarga agar dapat timbul rasa aman, tenteram, dan harapan masa depan yang lebih baik dalam mewujudkan kesejahteraan lahir dan kebahagiaan batin. Kemudian, disebutkan pula bahwa keluarga berkualitas adalah keluarga yang dibentuk berdasarkan perkawinan yang sah dan bercirikan sejahtera, sehat, maju, mandiri, memiliki jumlah anak yang ideal, berwawasan ke depan, bertanggung jawab, harmonis dan bertakwa kepada Tuhan Yang Maha Esa [10].

Oleh karenanya landasan legalitas perkawinan merupakan salah satu landasan penting bagi keluarga untuk membentuk sebuah keluarga harmonis yang sejahtera lahir dan batin. Perkawinan yang tidak sah akan menjadi hambatan dalam mencapai kesejahteraan dan ketahanan keluarga yang kuat karena perkawinan yang tidak sah mengandung resiko tidak terpenuhinya hak-hak anak dan isteri.

Berdasarkan Undang-undang Nomor 1 Tahun 1974 tentang Perkawinan yang dimaksud dengan perkawinan yang sah adalah jika dilakukan menurut hukum masing-masing agama dan kepercayaannya dan disamping itu perkawinan harus dicatat menurut peraturan perundang-undangan [8]. Pencatatan perkawinan berupa kutipan akta perkawinan yang menjadi alat bukti perkawinan yang sah yaitu berupa buku nikah isteri dan buku nikah suami. Sehingga landasan legalitas perkawinan dapat dilihat dari kepemilikan buku nikah dari pasangan suami dan istri tersebut. Hasil penelitian menunjukkan $100 \%$ responden telah memiliki buku (akte) nikah.

Selain kepemilikan buku nikah landasan legalitas juga dilihat dari legalitas kelahiran berupa kepemilikan akte kelahiran. Akte kelahiran merupakan bukti sah mengenai status dan peristiwa kelahiran seseorang yang dikeluarkan oleh Dinas Kependudukan dan Catatan Sipil. Bayi yang dilaporkan kelahirannya akan terdaftar dalam Kartu Keluarga (KK) dan diberi Nomor Induk Kependudukan (NIK) sebagai dasar untuk memperoleh pelayanan masyarakat lainnya. Kepemilikan akte kelahiran juga merupakan salah satu bukti telah terpenuhinya hak memiliki identitas sebagai anak. Hak identitas bagi seorang anak dinyatakan tegas dalam pasal 5 Undang-undang No. 23 Tahun 2002 tentang Perlindungan Anak, pasal tersebut menyebutkan bahwa "setiap anak berhak atas suatu nama sebagai identitas diri dan status kewarganegaraan" [9].

Sesuai dengan Undang-undang No. 35 tahun 2014, anak adalah seseorang yang belum berumur 18 (delapan belas) tahun, yang berarti bahwa setiap anak dengan umur tersebut berhak untuk memiliki akte kelahiran [11]. Berdasarkan hasil penelitian yang dilakukan $100 \%$ responden menyatakan seluruh anaknya telah memiliki akte kelahiran. Hal ini menunjukkan tingkat kepedulian dan juga kesadaran orang tua akan pentingnya akte kelahiran sebagai identitas diri untuk anak mereka. Meskipun berdasarkan wawancara yang dilakukan pengurusan akte kelahiran tidak dilakukan dengan segera oleh para orang tua. Adapun alasan utama yang dikemukan terkait dengan faktor ketidaktahuan.

Keluarga sebagai sebuah sistem sosial mempunyai sejumlah fungsi, seperti fungsi keagamaan, sosial budaya, cinta kasih, melindungi, reproduksi, sosialisasi dan pendidikan, ekonomi, pembinaan lingkungan [4]. Keluarga dapat terpecah atau tidak berfungsi secara normal apabila salah satu atau lebih 
anggota keluarga tidak atau gagal menjalankan tugas dan fungsinya. Salah satu contohnya adalah hubungan antar anggota keluarga yang tidak harmonis atau ikatan emosi antar anggota keluarga kurang terjalin dengan baik. Untuk menjamin keberlangsungan fungsi sosial tersebut maka setiap anggota keluarga harus tinggal bersama dalam satu atap, dengan ikatan emosional dan mempunyai kewajiban antara satu orang dengan orang yang lainnya. Itulah alasan mengapa keutuhan keluarga menjadi salah satu komponen dari ketahanan keluarga.

Peluang terjadinya kegagalan fungsi keluarga akan semakin besar ketika salah satu anggota keluarga, terutama suami atau istri tidak tinggal bersama dalam satu rumah. Hasil penelitian menunjukkan 52.6\% keluarga tinggal satu atap dan $47.4 \%$ keluarga lainnya tidak.

Gender menyangkut perbedaan peran, fungsi, tanggung jawab, kebutuhan dan status sosial antara laki-laki dan perempuan berdasarkan bentukan/konstruksi dari budaya masyarakat. Kemitraan dalam pembagian peran suami dan istri untuk mengerjakan aktivitas kehidupan keluarga menunjukkan adanya transparansi penggunaan sumberdaya, rasa saling ketergantungan berdasarkan kepercayaan dan saling menghormati sehingga terselenggaranya kehidupan keluarga yang harmonis. Dalam pembahasan selanjutnya kemitraan gender dalam keluarga dijelaskan melalui kemitraan suami-istri, keterbukaan pengelolaan keuangan, serta pengambilan keputusan keluarga.

Pembagian peran suami-istri dalam menjalankan fungsi keluarga mulai dari memberikan perhatian, bantuan moril dan material, sampai dengan bantuan tenaga dan waktu. Kemitraan gender dalam mengurus rumah tangga tidak hanya mencakup pekerjaan membersihkan rumah, memasak, mencuci pakaian dan sejenisnya, namun termasuk pula pengasuhan anak, seperti menemani anak belajar, dan bermain. Perhatian, kasih sayang dan pola asuh yang diterapkan orang tua pada anak-anak akan sangat berpengaruh terhadap tumbuh kembang anak-anak di masa yang akan datang. Oleh karena itu, diperlukan kerjasama antara suami dan istri dalam meluangkan waktu bersama dengan anak, agar kebersamaan dengan anak selalu terjalin dan pengasuhan anak tidak terhambat sehingga ketahanan keluarga dapat tercipta.

Kebersamaan bersama anak merupakan bentuk pendidikan dan perhatian orang tua dalam memahami sekaligus mengawasi tumbuh kembang anak. Willis [13] mengenalkan tiga bentuk pendekatan yang dilakukan oleh pendidik terhadap anak diantaranya adalah pendekatan psikologis, pedagosis, dan pendekatan sosiologis. Pendekatan psikologis untuk memahami perkembangan psikis anak, pendekatan pedagosis erat kaitannya dengan aspek pendidikan, ialah membantu anak agar cukup cakap dalam melaksanakan tugas hidupnya sendiri. Pendekatan sosiologis, berarti memahami kehidupan sosial mereka.

Waktu luang bersama keluarga dikelompoknya kedalam 3 kategori, yaitu lebih dari cukup (lebih dari 4 jam per hari), cukup ( 2 hingga 4 jam per hari), dan kurang (kurang dari 2 jam per hari). Hasil penelitian menunjukkan, suami-istri meluangkan waktunya lebih dari cukup bersama anak mereka.

Tabel 1. Tingkat Kebersamaan Keluarga

\begin{tabular}{clc}
\hline No & Kategori & Jumlah (\%) \\
\hline \hline 1. & Lebih dari Cukup & 52.6 \\
\hline 2. & Cukup & 18.4 \\
\hline 3. & Kurang & 28.9 \\
\hline
\end{tabular}

Sumber: Data Primer Diolah Tahun 2020

Berdasarkan penelitian yang telah dilakukan, $52.6 \%$ responden telah meluangkan waktunya lebih dari cukup bersama keluarga khususnya untuk anak mereka. Waktu tersebut biasanya digunakan oleh mereka untuk bermain atau berolahraga bersama, nonton ataupun berdiskusi bersama. Namun masih ditemukan sebesar $28.9 \%$ keluarga yang meluangkan waktunya untuk keluarga hanya kurang dari dua jam perhari. Hal ini disebabkan oleh faktor kesibukan orang tua dalam pekerjaan terutama ayah yang memperoleh penghasilan harian dari pekerjaannya misalnya berdagang, dan lain-lain.

Konsep kemitraan selanjutnya adalah relasi atau hubungan suami-istri dalam hal mengurus rumah tangga secara bersama-sama. Dalam keluarga konvensional, pola relasi suami-istri menempatkan lakilaki (suami) dalam peran produktif dan peran publik. Yang dimaksud peran produktif adalah sebagai pencari nafkah, sedangkan peran publik menempatkan suami sebagai pelindung keluarga. Sedangkan 
istri sebagai ibu rumah tangga yang mengurus rumah tangga (peran domestik), yaitu mencuci, memasak, mengasuh anak dan lain-lain. Konsep pola relasi tersebut telah mengalami pergeseran sesuai dengan perubahan kondisi sosial budaya masyarakat. Melalui kemitraan dan relasi gender yang harmonis, mereka dapat merencanakan dan melaksanakan manajemen sumberdaya keluarga sehingga terwujud keluarga yang memiliki ketahanan yang baik.

Hasil penelitian menunjukkan relasi atau hubungan antar suami dan istri telah terjalin dengan baik. Sebesar $81.6 \%$ kepala rumah tangga (suami) bersama pasangan mengurus rumah tangga secara bersama-sama. Namun masih ditemukan, $7.9 \%$ diantaranya beban tersebut tertumpu pada suami saja. Lebih lengkapnya disajikan pada tabel 2 berikut ini.

Tabel 2. Relasi Suami dan Istri

\begin{tabular}{clc}
\hline No & \multicolumn{1}{c}{ Kategori } & Jumlah (\%) \\
\hline \hline 1. & Kepala Rumah Tangga bersama Pasangan & 81.6 \\
\hline 2. & Kepala Rumah Tangga saja & 7.9 \\
\hline 3. & Pasangan saja & 0 \\
\hline 4. & Lainnya & 10.5 \\
\hline
\end{tabular}

Sumber: Data Primer Diolah Tahun 2020

Kemitraan gender juga dapat dilihat dari adanya transparansi pengelolaan keuangan dalam keluarga. Keterbukaan pengelolaan keuangan dinilai dari kerja sama antara suami dan istri dalam mengambil keputusan yang menyangkut pengelolaan keuangan keluarga. Umumnya, jika suami yang bekerja maka ia harus melaporkan seluruh pendapatannya kepada istri dan menyerahkan sebagian besar pendapatannya kepada istri. Sebaliknya, meskipun istri memegang kendali keuangan keluarga, namun ia harus selalu mengkomunikasikan pemanfaatan uang yang dikelolanya. Itulah salah satu contoh keterbukaan dalam pengelolaan keuangan keluarga.

Hasil penelitian menunjukkan keputusan pengelolaan keuangan keluarga telah dilakukan bersama antara suami dan istri. Sebasar $65.8 \%$ responden mengelola keuangan secara bersama dengan pasangannya. Namun ditemukan masih dominannya peran istri dalam mengambil keputusan penggunaan penghasilan yaitu sebesar $23.7 \%$ dibanding dengan peran suami hanya $10.5 \%$.

Tabel 3. Penentu Keputusan Penggunaan Penghasilan

\begin{tabular}{clc}
\hline No & \multicolumn{1}{c}{ Kategori } & Jumlah (\%) \\
\hline \hline 1. & Suami beserta Istri & 65.8 \\
\hline 2. & Suami & 10.5 \\
\hline 3. & Istri & 23.7 \\
\hline 4. & Pihak Lain & 0 \\
\hline
\end{tabular}

Sumber: Data Primer Diolah Tahun 2020

Selain keterbukaan dalam pengelolaan keuangan, pengambilan keputusan keluarga juga menjadi salah satu indikator ketahanan keluarga. Pengambilan keputusan keluarga yang dimaksud disini adalah adanya pembahasan mengenai pengambilan keputusan yang berkaitan dengan keluarga. Jadi, meskipun suami yang berperan sebagai kepala keluarga, namun dalam menjalankan tugasnya tidak boleh otoriter, harus mengakomodir kepentingan anggota keluarga yang lain serta mempertimbangkan masukan dan saran dari istri dan juga anak-anaknya. Dalam pembahasan selanjutnya, pengambilan keputusan keluarga akan dilihat melalui pengambilan keputusan untuk penentuan jumlah anak.

Tabel 4. Penentu Jumlah Anak

\begin{tabular}{clc}
\hline No & \multicolumn{1}{c}{ Kategori } & Jumlah (\%) \\
\hline \hline 1. & Suami dan Istri & 94.7 \\
\hline 2. & Suami & 0 \\
\hline 3. & Istri & 5.3 \\
\hline 4. & Pihak Lain & 0 \\
\hline
\end{tabular}

Sumber: Data Primer Diolah Tahun 2020

Hasil penelitian menunjukkan dalam hal penentuan jumlah anak suami dan istri telah menjalin komunikasi yang baik. Persentase rumah tangga yang menentukan jumlah anak secara bersama oleh suami dan istri jumlahnya sangat tinggi yaitu sebesar $94.7 \%$. Data pada tabel 4 juga menunjukkan masih terdapat peran dominan istri dalam penentuan jumlah anak meskipun hanya terdapat pada 
sebagian kecil rumah tangga.

Dalam membentuk keluarga yang mempunyai ketahanan fisik yang bagus, maka sangat penting untuk memperhatikan kecukupan pangan dan status gizi yang baik bagi seluruh anggota keluarga. Kondisi fisik yang tangguh, mental yang kuat, kesehatan yang prima, serta cerdas sangat ditentukan oleh status gizi yang baik, sedangkan status gizi yang baik ditentukan oleh jumlah asupan pangan yang dikonsumsi. Hasil penelitian menunjukkan sebagian rumah tangga dengan seluruh anggota keluarganya telah makan minimal 2 kali per hari dan makan dengan lengkap meliputi makanan pokok, lauk pauk nabati dan juga lauk pauk hewani.

Dari hasil penelitian didapatkan bahwa seluruh anggota keluarga masih belum terpenuhi untuk dapat makan secara lengkap, yaitu terdapat makanan pokok, lauk nabati dan lauk hewani. Sebanyak $50 \%$ responden mengatakan bahwa seluruh anggota keluarga telah makan makanan dengan komponen lengkap, dan 50\% responden mengatakan seluruh anggota keluarga setiap harinya belum makan makanan lengkap untuk memenuhi kebutuhan gizinya. Hal ini menjadi tugas penting bagi stakeholder terkait baik dari pemerintah daerah dan juga kader kader masyarakat untuk dapat memberikan stimulasi bahkan bantuan masyarakat agar dapat makan makanan bergizi setiap harinya.

Komponen berikutnya dari indikator ketahanan fisik adalah kesehatan seluruh anggota keluarga. Kesehatan anggota keluarga merupakan komponen penting dalam melihat sejauh mana tingkat ketahanan keluarga di bidang fisik. Jika seluruh anggota keluarga sehat dari segi jasmani dan rohani maka ketahanan keluarga akan tinggi. Dalam penelitian ini kesehatan keluarga diukur melalui kecukupan gizi balita di setiap keluarga dan seberapa banyak anggota keluarga yang mengidap penyakit mulai dari kronis sampai disabilitas. Berikut merupakan grafik yang menunjukkan tingkat kecukupan gizi balita.

Dari hasil penelitian ditunjukkan bahwasannya mayoritas balita di Kabupaten Bandung telah mendapatkan kecukupan gizi yang baik. Sebanyak $83.3 \%$ responden mengatakan bahwa balita yang ada dalam keluarganya telah mendapatkan gizi baik, dan sisanya sebesar $16.7 \%$ responden menjawab bahwasannya balita yang berada di keluarganya belum mendapatkan gizi yang baik. Gizi balita akan mempengaruhi tumbuh kembang sampai ia dewasa kelak. Kekurangan gizi dapat mengakibatkan stunting yang diderita oleh Balita. Stunting ini merupakan salah satu permasalahan pada anak yang mengganggu perkembangan tumbuh kembangnya, sehingga banyak program yang digagas oleh pemerintah daerah yang bekerjsama dengan tenaga kesehatan yang difasilitaori oleh dokter anak untuk menurunkan angka stunting.

Tabel 5. Penyakit yang Diderita Anggota Keluarga

\begin{tabular}{clc}
\hline No & \multicolumn{1}{c}{ Kategori } & Jumlah (\%) \\
\hline \hline 1. & Suami dan Istri & 94.7 \\
\hline 2. & Suami & 0 \\
\hline 3. & Istri & 5.3 \\
\hline 4. & Pihak Lain & 0
\end{tabular}

Sumber: Data Primer Diolah Tahun 2020

Komponen di bidang kesehatan yang turut mempengaruhi tingkat ketahanan keluarga adalah seberapa banyak anggota keluarga yang menderita penyakit kronis dan diasbilitas. Dari hasil penelitian didapatkan bahwa masyarakat Kabupaten Bandung mayoritas dalam keadaan yang baik dan sehat. Sebesar $92,1 \%$ respondem menjawab bahwa seluruh anggota keluarga tidak memiliki penyakit kronis maupun disabilitas, sebanyak 2,6\% responden menjawab anggota keluarga memiliki kondisi disablitas tanpapenyakit kronis, kemudian sebesar $5,3 \%$ responden menjawab anggota keluarga memiliki penyakit kronis tanpa disabilitas.

Komponen ketahanan fisik selanjutnya adalah ketersediaan tempat atau lokasi tetap untuk tidur. Dalam komponen ini, peneliti ingin melihat seberapa banyak anggota keluarga yang memiliki tempat tinggal tetap untuk hidup. Dengan mengetahui seberapa banyak rumah tangga yang memiliki tempat tinggal, maka ketahanan keluarga akan baik dikarenakan tersedianya tempat tinggal yang layak dan terjamin. Seluruh anggota keluarga membutuhkan tempat layak huni untuk melangsungkan hidupnya. Ketika tempat tinggal tidak layak untuk dihuni maka akan berpengaruh terhadap kesehatan mental serta fisik anggota keluarga. Berikut merupakan grafik dari ketersediaan tempat tidur bagi seluruh anggota keluarga. 
p-ISSN: $2655-7304$

e-ISSN: $6655-8953$

Hasil penelitian menunjukkan bahwa seluruh responden atau 100\% responden menyatakan bahwa di masing-masing tempat tinggal mereka terdapat tempat tidur yang digunakan oleh maksimal 3 orang. Hal ini juga memberikan gambaran bahwa keseluruhan responden sudah terpenuhi kebutuhan untuk kenyamanan tempat tinggalnya.

Komponen lain yang dapat membentuk ketahanan keluarga adalah ketahanan dari sisi ekonomi. Ketahanan ekonomi keluarga menjadi hal yang penting terutama dalam rangka menghadapi berbagai kebutuhan dan tuntutan ekonomi keluarga. Keluarga yang memiliki ketahanan ekonomi yang baik cenderung memiliki tingkat kesejahteraan yang baik pula. Tidak hanya itu, ketahanan ekonomi keluarga juga dapat meningkatkan kebahagiaan serta mendorong keluarga untuk dapat mempersiapkan generasi selanjutnya dengan baik.

Terdapat beberapa hal yang dapat digunakan untuk menilai ketahanan ekonomi keluarga, yaitu dari tempat tinggal keluarga, pendapatan keluarga, pembiayaan pendidikan anak, dan jaminan keuangan keluarga. Penjelasan masing-masing komponen tersebut dan gambaran kondisi ketahanan ekonomi keluarga di Kabupaten Bandung akan diuraikan dibawah ini.

Tempat tinggal keluarga menjadi salah satu kompenen penting untuk menilai ketahanan ekonomi sebuah keluarga. Hal tersebut berkenaan dengan kemampuan keluarga dalam memiliki asset keluarga yang berbentuk fisik. Kepemilikan tempat tinggal ini kemudian dapat dikaitkan dengan bagaimana kemampuan keluarga untuk menggali potensi-potensi ekonominya untuk mengasilkan pendapatan sehingga dapat memiliki tempat tinggal. Lebih jauh lagi, tempat tinggal keluarga ini dapat menjadi instrument investasi yang memiliki nilai untuk masa yang akan datang.

Tempat tinggal merupakan salah satu kebutuhan primer masyarakat yang sifatnya wajib terpenuhi. Bagi masyarakat yang memiliki pendapatan yang cukup untuk membeli tempat tinggal maka hal tersebut tidak menjadi masalah. Namun, ada berbagai kondisi di masyarakat yang membuat cara untuk memenuhi kebutuhan terhadap tempat tinggal tersebut beragam, misalnya dengan mengontrak, menumpang, dan lain-lain.

Tempat tinggal keluarga ini kemudian menjadi pertanyaan yang diberikan kepada responden dalam penelitian ini untuk dapat mengukur tingkat ketahanan ekonomi keluarga. Berdasarkan hasil penelitian, diketahui sebanyak $86.8 \%$ tinggal di tempat tinggal milik sendiri. Sedangkan responden tinggal mengontrak dan menumpang di tempat keluarga/kerabat masing-masing $5.3 \%$. Sebanyak $2.6 \%$ responden menyatakan tidak tinggal tinggal di rumah milik sendiri, mengontrak, maupun menumpang di tempat keluarga/kerabat. Berikut ini adalah gambar yang menunjukan presentase tempat tinggal keluarga.

Tabel 6. Kepemilikan Rumah

\begin{tabular}{clc}
\hline No & \multicolumn{1}{c}{ Kategori } & Jumlah (\%) \\
\hline \hline 1. & Milik Sendiri & 86.8 \\
\hline 2. & Mengontrak & 5.3 \\
\hline 3. & Menumpang ditempat Keluarga/Kerabat & 5.3 \\
\hline 4. & Lainnya & 2.6
\end{tabular}

Sumber: Data Primer Diolah Tahun 2020

Data pada tabel 6 memperlihatkan bahwa mayoritas responden penelitian tinggal di rumah dengan kepemilikan pribadi. Hal tersebut menunjukan bahwa mayoritas masyarakat memiliki kemampuan secara ekonomi untuk memiliki asset pribadi, walaupun cara yang digunakan untuk pemenuhannya bisa beragam, misalnya dengan menggunakan sistem kredit perbankan.

Pengukuran terhadap ketahanan ekonomi keluarga selanjutnya adalah dari kemampuan keluarga untuk menghasilkan pendapatan untuk kepentingan keluarga. Asumsinya bahwa semakin besar pendapatan keluarga maka tingkat kesejahteraan keluarga juga semakin tinggi. Pendapatan keluarga ini merupakan pendapatan yang diperoleh baik oleh kepala keluarga maupun anggota keluarga untuk memenuhi kebutuhan keluarga.

Untuk mempermudah memahami gambaran besar pendapatan keluarga yang ada di Kabupaten Bandung maka digunakan pengelompokan/ kategorisasi berdasarkan perkiraan jumlah pendapatan keluarga, yaitu $>750.000,500.000-750.000,250.000-500.000,<250.000$. Pengelompokan ini 
p-ISSN: $2655-7304$

e-ISSN: $6655-8953$

kemudian juga dapat memberikan informasi tentang tingkat kesejahteraan keluarga.

Dari hasil penelitian, diketahui bahwa sebanyak $63.2 \%$ responden menyatakan bahwa pendapatan yang diterima keluarganya setiap bulan lebih dari 750.000 . Kemudian sebanyak $23.7 \%$ menyatakan pendapatan keluarganya ada pada rentang 500.000-750.000. Sedangkan $10.5 \%$ menyatakan pendapatan keluarganya ada pada retang 250.000-500.000. Lalu sebanyak $2.6 \%$ menyatakan bahwa pendapat keluarganya kurang dari 250.000 per bulan.

Tabel 7. Pengeluaran Rumah Tangga

\begin{tabular}{clc}
\hline No & \multicolumn{1}{c}{ Kategori } & Jumlah (\%) \\
\hline \hline 1. & $>750.000$ & 63.2 \\
\hline 2. & $500.000-750.000$ & 23.7 \\
\hline 3. & $250.000-500.000$ & 10.5 \\
\hline 4. & $<250.000$ & 2.6 \\
\hline
\end{tabular}

Sumber: Data Primer Diolah Tahun 2020

Dari perolehan data tersebut dapat diketahui bahwa tingkat pendapatan keluarga cukup beragam yang didominasi oleh kelompok dengan pendapatan lebih dari 750.000. Namun ternyata masih ada responden dengan tingkat pendapatan keluarga yang lebih rendah dari 750.000 perbulan sebanyak total $36.8 \%$. Hal ini tentu bisa memberikan gambaran tentang seberapa besar kemampuan keluarga untuk menghasilkan pendapatan.

Pengukuran terhadap tingkat ekonomi keluarga tidak hanya soal angka, tetapi juga dari persepsi tingkat kecukupan pendapatan untuk memenuhi kebutuhan keluarga. Maka dari itu, pertanyaan tentang persepsi kecukupan pendapatan rumah tangga juga menjadi salah satu pertanyaan yang terdapat di kuesioner. Dari hasil penelitian, didapatkan bahwa sebanyak $10.5 \%$ responden menganggap bahwa pendapatan keluarga yang diterimanya dapat lebih dari cukup memenuhi kebutuhan keluarga. Kemudian, sebanyak $63 \%$ reseponden menganggap bahwa pendapatan keluarga yang diterima telah cukup untuk memenuhi kebutuhan keluarga. Terdapat $26.3 \%$ responden yang menyatakan bahwa pendapatan yang diterima keluarga selama ini masih kurang untuk memenuhi kebutuhan keluarga.

Tabel 8. Kecukupan Pendapatan Rumah Tangga

\begin{tabular}{clc}
\hline No & \multicolumn{1}{c}{ Kategori } & Jumlah (\%) \\
\hline \hline 1. & Lebih dari Cukup & 10.5 \\
\hline 2. & Cukup & 63.2 \\
\hline 3. & Kurang & 26.3 \\
\hline
\end{tabular}

Sumber: Data Primer Diolah Tahun 2020

Dari data tersebut dapat diketahui bahwa beragamnya tingkat pendapatan responden, mayoritas persepsi responden menyatakan bahwa pendapatan keluarganya masuk pada kategori cukup. Persepsi tingkat kecukupan dari responden ini dipengaruhi oleh pengaturan keuangan keluarga, pola hidup sederhana, dan penerimaan terhadap hal yang sudah diperoleh keluarga. Perolehan data tersebut sangat dipengaruhi oleh subjektifitas responden karena memang penggalian informasi diarahkan pada persepsi responden.

Pendidikan saat ini telah menjadi hal yang krusial pemenuhannya sebagai upaya membentuk pribadi-pribadi yang unggul dan berkualitas. Maka dari itu, setiap keluarga saat ini didorong untuk dapat menyekolahkan setiap anggota dalam keluarganya sampai 12 tahun pada jenjang sekolah menengah atas. Menyekolahkan anggota keluarga ini tentu bukan hal yang mudah bagi setiap keluarga karena berkaitan dengan kemampuan pembiayaan keluarga untuk pendidikan anggota keluarga. Maka dari itu, untuk mengukur tingkat ketahanan ekonomi keluarga salah satu indikator yang dapat digunakan adalah seberapa mampu sebuah keluarga menyekolahkan anggota keluarganya.

Dari hasil penelitian dapat diketahui bahwa sebanyak 92.1\% responden menyatakan bahwa seluruh anggota keluarganya bersekolah, yang dalam hal ini statusnya bisa masih bersekolah atau sudah lulus sekolah. Sebanyak 5.3\% menyatakan sebagian bersekolah dan $2.6 \%$ menyakatan tidak ada yang bersekolah. 
Tabel 9. Anggota RT yang Bersekolah

\begin{tabular}{clc}
\hline No & \multicolumn{1}{c}{ Kategori } & Jumlah (\%) \\
\hline \hline 1. & Seluruhnya Bersekolah & 92.1 \\
\hline 2. & Sebagian Bersekolah & 5.3 \\
\hline 3. & Tidak Ada yang Bersekolah & 2.6 \\
\hline
\end{tabular}

Sumber: Data Primer Diolah Tahun 2020

Dari data tersebut dapat diketahui bahwa mayoritas responden memiliki keluarga yang seluruhnya bersekolah yang berarti mayoritas memiliki kemampuan pembiayaan sekolah bagi anggota keluarganya. Tetapi nyatanya masih ada juga keluarga yang seluruh anggota keluarganya tidak bersekolah. Kemudian, masih ada keluarga yang hanya Sebagian keluarga yang bersekolah sering kali karena belum sampai pada usia masuk sekolah ataupun putus sekolah. Berikut adalah data yang diperoleh tentang ada atau tidaknya anggota keluarga yang putus sekolah.

Dari gambar diatas dapat diperoleh bahwa sebanyak $92.1 \%$ responden menyatakan bahwa tidak ada anggota keluarga yang putus sekolah. Sedangkan sebanyak $7.9 \%$ memiliki anggota keluarga yang mengalami putus sekolah. Kejadian putus sekolah ini biasanya terjadi karena tidak memiliki pembiayaan yang cukup untuk sekolah.

Untuk memastikan bahwa sebuah keluarga memiliki ketahanan ekonomi keluarga yang baik maka keluarga perlu memiliki kesiapan dalam menghadapi situasi apapun. Maka dari itu, keluarga perlu memiliki jaminan atas resiko yang bisa terjadi menimpa anggota keluarga. Jaminan yang dimaksud tersebut bisa dalam bentuk tabungan/simpanan keluarga. Keluarga yang memiliki tabungan/simpanan memiliki potensi untuk dapat menghadapi situasi yang tidak menentu di masa yang akan datang. Maka dari itu, pertanyaan tentang kepemilikan tabungan/simpanan ini juga turut ditanyakan kepada responden untuk mengukur tingkat ketahanan ekonomi keluarganya. Berikut adalah data yang diperoleh dari hasil penelitian.

Tabel 10. Keluarga Memiliki Tabungan

\begin{tabular}{clc}
\hline No & \multicolumn{1}{c}{ Kategori } & Jumlah (\%) \\
\hline \hline 1. & Punya $>500.000$ & 36.8 \\
\hline 2. & Punya $<500.000$ & 21.1 \\
\hline 3. & Tidak Punya & 42.1 \\
\hline
\end{tabular}

Sumber: Data Primer Diolah Tahun 2020

Tabel 10 menunjukkan bahwa lebih dari setengah responden menyatakan bahwa keluarganya memiliki tabungan/simpanan. Terdapat $36.8 \%$ menyatakan bahwa memiliki tabungan lebih dari 500.000 dan hanya $21.1 \%$ yang menyakan memiliki tabungan/simpanan kurang dari 500.000. Kemudian, sebanyak $42.1 \%$ responden menyatakan bahwa keluarganya tidak memiliki tabungan/simpanan. Dari data tersebut dapat dilihat bahwa hampir setengah responden belum dapat mengalokasikan Sebagian pendapatannya untuk ditabung. Bukan karena tidak memiliki kesadaran untuk memiliki tabungan/simpanan sama sekali, namun lebih pada adanya kebutuhan saat ini yang harus segera dipenuhi.

Selain terkait dengan adanya resiko finansial, ada juga resiko lain yang dihadapi oleh setiap keluarga yaitu resiko kesehatan. Sering kali, keluarga yang tidak mempersiapkan jaminan atas ancaman besar dari resiko Kesehatan ini mengalami hambatan ekonomi yang cukup besar di masa yang akan datang. Maka dari itu, keluarga dapat dikatakan memiliki ketahanan ekonomi yang baik Ketika memiliki jaminan Kesehatan atau asuransi Kesehatan untuk keluarganya. Hal ini yang turut ditanyakan kepada para responden dalam penelitian ini dan berikut adalah data yang diperoleh.

Tabel 11. Anggota RT yang Memiliki Asuransi Kesehatan

\begin{tabular}{clc}
\hline No & \multicolumn{1}{c}{ Kategori } & Jumlah (\%) \\
\hline \hline 1. & Semua & 52.6 \\
\hline 2. & Sebagian & 23.7 \\
\hline 3. & Tidak Ada & 23.7 \\
\hline
\end{tabular}

Sumber: Data Primer Diolah Tahun 2020

Berdasarkan data pada tabel 11 diketahui bahwa sebanyak 52.6\% responden menyatakan bahwa seluruh anggota keluarganya memiliki asuransi Kesehatan, baik yang asurnasi Kesehatan yang 
penyelenggaranya pemerintah maupun swasta. Namun, sebanyak $23.7 \%$ menyakan bahwa hanya Sebagian keluarganya yang memiliki asuransi Kesehatan. Dan sebanyak $23.7 \%$ responden menyatakan bahwa tidak ada satupun dalam anggota keluarga memiliki asuransi Kesehatan. Hal tersebut menunjukan bahwa masih ada keluarga yang belum memiliki jaminan Kesehatan atas anggota keluarganya sehingga masih memiliki ancaman terhadap resiko dari adanya masalah Kesehatan dikemudian hari.

Seperti yang diketahui bahwasannya keluarga menjadi sebuah komponen penting didalam masyarakat sebagai tempat individu membentuk kelompok terkecilnya. Keluarga merupakan sebuah konsep yang memiliki pengertian dan cakupan yang luas dan beragam. Keluarga, dalam konteks sosiologi, dianggap sebagai suatu institusi sosial yang sekaligus menjadi suatu sistem sosial yang ada di setiap kebudayaan [2]. Beberapa unsur yang terdapat dalam ketahanan sosial psikologi menurut konsep ketahanan dan kesejahteraan keluarga dalam Peraturan Menteri PPPA Nomor 6 Tahun 2013 tentang Pelaksanaan Pembangunan Keluarga, diantaranya mencakup: (1) Landasan Legalitas dan Keutuhan Keluarga, (2) Ketahanan Fisik, (3) Ketahanan Ekonomi, (4) Ketahanan Sosial Psikologi, dan (5) Ketahanan Sosial Budaya [5].

Faktor ketahanan sosial psikologi merupakan salah satu unsur terbentuknya ketahanan keluarga. Ketahanan sosial psikologi mencakup bagaimana seluruh anggota keluarga dapat merasakan bagaimana hidup dengan harmonis dan nyaman dalam lingkup internal maupun eksternal. Ketika sebuah keluarga merasakan kenyamanan dalam menjalani kehidupan, maka akan terbangun sebuah kepercayaan diri yang akan berpengaruh terhadap eksistensi dalam suatu hubungan kemasyarakatan. Kontribusi yang dihasilkan oleh anggota keluarga untuk kehidupan sosial akan lebih optimal dengan adanya ketahanan sosial psikologi. Dalam ketahanan sosial psikologi, terdapat dua faktor yang mempengaruhi tingkat ketahanan keluarga, yaitu faktor keharmonisan keluarga dan kepatuhan terhadap hukum.

Konsep keharmonisan keluarga menjadi tolak ukur dalam ketahanan keluarga di bidang sosial psikologi. Keluarga yang harmonis diartikan bahwa seluruh anggota keluarga mendapat kehidupan yang layak dan hidup bahagia. Dalam konsep keharmonisan keluarga, anggota keluarga tidak ada yang terancam hidupnya dan terjamin dalam menjalankan perannya sebagai anggota keluarga.

Salah satu bagian dalam keharmonisan keluarga adalah hubungan antara suami dan istri. Hasil penelitian menunjukkan bahwa, keluarga yang harmonis ditunjukkan dengan tidak adanya kekerasan dalam rumah tangga. Dalam penelitian ini ditunjukkan bahwa seorang istri tidak setuju terhadap kekerasan dalam rumah tangga dengan kondisi dan alas an apapun. Dari hasil penelitian, sebanyak $92,1 \%$ menunjukkan bahwa istri tidak setuju dan tidak pernah mendapatkan kekerasan lahir maupun batin dalam rumah tangga dengan alasan dan kondisi tertentu, dan 7,9\% menunjukkan bahwa istri setuju dan pernah mendapatkan kekerasan lahir maupun batin dalam rumah tangga dengan alasan dan kondisi tertentu.

Konsep selanjutnya dalam keharmonisan keluarga selain adanya kekerasan suami terhadap istri adalah tingkat kekerasan terhadap anak oleh orang tuanya. Keluarga yang harmonis ditunjukkan dengan kasih sayang yang diberikan orang tua kepada anaknya. Karena dengan adanya kasih sayang dalam keluarga, maka anak dapat dilindungi haknya dan hidup secara bahagia, sehat, dan aman. Sebaliknya jika anak diperlakukan tidak baik dalam suau keluarga bahkan menjadi korban kekerasan, maka yang terjadi adalah anak menjadi terpuruk lahir dan batin sehingga tidak dapat hidup sebagaimana mestinya yang nantinya akan mempengaruhi tingkat keharmonisan keluarga.

Hasil penelitian menunjukkan bahwa mayoritas orang tua di Kabupaten Bandung telah teredukasi terkait dengan perannya untuk memberikan kasih sayang dan memfasilitasi tumbuh kembang anak. Dari hasil penelitian didapatkan bahwa $86,8 \%$ orang tua tidak pernah melakukan tindak kekerasan lahir maupun batin terhadap anak dan 13,2\% pernah melakukan kekerasan lahir maupun batin terhadap anak. sikap anti kekerasan terhadap anak. Hal ini dapat berpengaruh terhadap kualitas keharmonisan keluarga di Kabupaten Bandung. Ketika seorang anak jauh dari tindakan kekerasan, maka anak akan merasa hidupnya terjamin dan terlindungi sehingga anak menjadi lebih percaya diri, mudah bergaul dan dapat mengoptimalkan serta mengembangkan potensinya. Sebaliknya, jika anak merasa tidak nyaman dan diperlakukan secara tidak baik, maka perkembangan jiwa dan emosianalnya tentu akan terganggu.

Kepatuhan terhadap hukum juga menjadi salah satu faktor dalam ketahanan sosial dan psikologi. Indikator masyarakat yang patuh hukum menandakan bahwasannya masyarakat telah menerima edukasi dan dapat memahami akan pentingnya patuh terhadap hukum. Adanya pemahaman masyarakat 
untuk patuh terhadap hukum akan berdampak pada ketertiban dan keamanan hidup bermasyarakat.

Hasil dari penelitian ini menghasilkan kesimpulan bahwasannya masyarakat telah paham akan pentingnya patuh hukum. Salah satu indikator patuh terhadap hukum adalah masyarakat tidak pernah menjadi korban tindak pidana. Hasil penelitian menunjukkan 100\% masyarakat tidak pernah menjadi korban tindak pidana.

Konsep ketahanan keluarga selanjutnya berkaitan dengan ketahanan sosial budaya. Dalam ketahanan sosial budaya terdapat indikator kepedulian sosial yang di dalamnya terdapat unsur keaktifan masyarakat terhadap kegiatan sosial dan keaktifan masyarakat dalam kegiatan keagamaan serta adanya indikator keeratan sosial yang menekankan hubungan kemasyarakatan.

Kepedulian sosial merupakan salah satu indikator yang ada dalam konsep ketahanan sosial budaya. Kepedulian sosial diartikan sebagai bentuk kepekaan masyarakat terhadap kegiatan kemasyarakatan, dan seberapa jauh kontribusi yang diberikan masyarakat terhadap kegiatan kemasyarakatan. Untuk melihat seberapa jauh kepedulian masyarakat, peneliti menekankan pada bagaimana keaktifan masyarakat dalam mengikuti kegiatan sosial yang ada dalam lingkungan tempat tinggalnya.

Tabel 12. Aktif dalam Kegiatan Sosial

\begin{tabular}{|c|c|c|}
\hline No & Kategori & Jumlah (\%) \\
\hline 1. & Selalu & 36.8 \\
\hline 2. & Sering & 50.0 \\
\hline 3. & Jarang & 13.2 \\
\hline 4 & Tidak Pernah & 0 \\
\hline
\end{tabular}

Sumber: Data Primer Diolah Tahun 2020

Hasil riset menunjukkan bahwa mayoritas masyarakat aktif dalam kegiatan sosial di tempat tinggalnya. Sebanyak $36.8 \%$ responden menunjukkan selalu aktif dalam kegiatan sosial kemasyarakatan yang artinya masyarakat memiliki jadwal berkegiatan sosial secara rutin dan terjadwal. Kemudian sebanyak 50.0\% masyarakat masuk kategori sering mengikuti kegiatan sosial kemasyarakatan. Sebanyak 13.2\% masyarakat masuk kategori jarang mengikuti kegiatan sosial kemasyarakatan.

Tabel 13. Aktif dalam Kegiatan Keagamaan

\begin{tabular}{|c|c|c|}
\hline No & Kategori & Jumlah (\%) \\
\hline 1. & Selalu & 34.2 \\
\hline 2. & Sering & 57.9 \\
\hline 3. & Jarang & 7.9 \\
\hline 4 & Tidak Pernah & 0 \\
\hline
\end{tabular}

Sumber: Data Primer Diolah Tahun 2020

Indikator selanjutnya dalam menunjukkan kepedulian sosial dalam kemasyrakatan selain kontribusi aktif dalam mengikuti kegiatan sosial kemasyarakatan adalah keaktifan mengikuti kegiatan keagamaan. Dari hasil penelitian didapatkan bahwasannya sebanyak $34.2 \%$ responden selalu aktif mengikuti kegiataan keagamaan, mayoritas masyarakat sebanyak 57,9\% sering mengikuti kegiatan keagamaan, dan sebanyak 7,9\% masyarakat jarang mengikuti kegiatan keagamaan. Hal ini menunjukkan bahwasannya kepedulian masyarakat untuk aktif dalam kegiatan sosial maupun kegiatan keagamaan di tempat tinggal sudah masuk dalam kategori aktif.

\section{KESIMPULAN DAN SARAN}

Ketahanan keluarga merujuk pada sebuah kondisi dimana keluarga memiliki kemampuan untuk dapat mandiri dan mengembangkan keluarganya sehingga dapat harmonis, sejahtera, dan bahagia. Dengan keluarga yang kokoh akan membentuk masyarakat yang memiliki daya tahan sehingga ketahanan nasional dengan mudah terwujud. Problem adanya potensi kerentanan keluarga, baik yang disebabkan oleh faktor internal maupun faktor eksternal keluarga, menjadi penghambat upaya mewujudkan ketahanan keluarga. Keluarga dapat dikatakan memiliki ketahanan jika memenuhi aspekaspek ketahanan legalitas dan keutuhan keluarga, ketahanan fisik, ketahanan ekonomi, ketahanan sosial 
psikologi, dan ketahanan sosial budaya.

Dari aspek legalitas dan keutuhan keluarga, keluarga di Kabupaten Bandung sudah memiliki kesadaran atas pemenuhan aspek legalitasnya sebagai keluarga yang ditandai dengan kepemilikan dokumen kependudukan. Namun, dari sisi pemenuhan kebutuhan terhadap fungsi sosial dan ikatan emosional rumah tangga, masih banyak keluarga yang tidak tinggal bersama dalam satu atap dengan sebab berbagai macam kondisi keluarga. Hal tersebut kemudian berimplikasi pada tingkat kebersamaan dalam keluarga. Namun meskipun begitu, kepengurusan rumah tangga termasuk pengelolaan keuangan keluarga masih mayoritas dilakukan bersama-sama antara suami dan istri. Dari penjabaran tersebut dapat disimpulkan bahwa ketahanan keluarga dari aspek legalitas sudah sangat baik. Sedangkan untuk aspek keutuhan keluarga sudah cukup baik namun masih menghadapi sejumlah persoalan terkait kebersamaan keluarga.

Aspek selanjutnya adalah aspek fisik sebagai salah satu komponen pembentuk ketahanan keluarga. Dari hasil penelitian diketahui bahwa hanya Sebagian keluarga yang dapat memenuhi kecukupan pangan lengkap. Namun walaupun begitu, keluarga Sebagian besar sudah memperhatikan kecukupan gizi pada balita di keluarga. Selain itu, kondisi fisik keluarga relatif sehat dimana mayoritas tidak memiliki penyakit kronis dan tidak disabilitas. Kemudian untuk pemenuhan sarana fisik keluarga, tempat tidur keluarga sudah tersedia dan digunakan tidak lebih dari tiga orang. Dari penjabaran tersebut dapat disimpulkan bahwa dari aspek fisik sudah baik, adapun persoalan masih terjadi pada pemenuhan jenis pangan yang lengkap untuk keluarga.

Ketahanan dari sisi ekonomi juga berdampak pada ketahanan keluarga. Ketahanan ekonomi ini kemudian dapat dilihat dari beberapa hal. Dari hasil penelitian dapat diketahui bahwa mayoritas kepemilikan rumah adalah milik sendiri yang berarti mayoritas memiliki kemampuan untuk memenuhi kebutuhan tempat tinggal pribadi. Kemudian, dari sisi pendapatan keluarga, sudah lebih dari setengah masyarakat yang dapat hidup dengan sederhana dan memenuhi kebutuhan pokoknya, termasuk untuk pembiayaan sekolah. Namun, Sebagian keluarga masih terkendala dalam menyisihkan anggaran keluarga untuk tabungan dan pembiayaan asuransi Kesehatan. Dari penjabaran tersebut dapat disimpulkan bahwa dari sisi ketahanan ekonomi, keluarga sudah dapat memenuhi kebutuhannya untuk masa sekarang namun dalam kondisi tertentu atau darurat keluarga cukup rentan untuk menghadapi kondisi sulit atau tidak terduga.

Ketahanan keluarga juga dapat dilihat dari aspek ketahanan sosial psikologi keluarga. Dari hasil penelitian diketahui bahwa mayoritas keluarga sudah memiliki kesadaran untuk tidak melakukan kekerasan dalam rumah tangga. Angka kekerasan terhadap istri ada tapi relatif kecil, berbeda dengan angka kekerasan terhadap anak yang lebih besar dibandingkan terhadap istri. Kekerasan terhadap anak ini dilakukan selama proses pengasuhan.

Ketahanan sosial budaya menjadi faktor lain yang membentuk ketahanan keluarga. Ketahanan sosial budaya ini dapat dilihat dari keaktifan keluarga dalam berbagai kegiatan sosial dan keagamaan. Dari hasil penelitian dapat diketahui bahwa tidak ada keluarga yang tidak mengikuti baik kegiatan sosial maupun kegiatan keagamaan, walaupun tingkat keterlibatannya berbeda-beda. Dari hal tersebut dapat disimpulkan bahwa mayoritas masyarakat sudah terlibat pada aktifitas di dalam kelompok masyarakat dimana dapat terpengaruh atau mempengaruhi dinamika yang ada di masyarakat.

Untuk meningkatkan dan memperkokoh ketahanan keluarga di Kabupaten Bandung agar dapat meningkatkan ketahanan nasional, perlu ditumbuhkan kesadaran dan pengetahuan masyarakat tentang pentingnya fungsi keluarga. Dinas P2KBP3A Kabupaten Bandung memiliki peran yang sangat penting untuk memastikan unsur-unsur penggerak lapangan seperti penyuluh $\mathrm{KB}$ dan kader-kader $\mathrm{KB}$ dapat secara efektif melakukan tugas dan fungsinya

Dalam upaya memperbaiki dan meningkatkan aspek-aspek di dalam ketahanan keluarga, juga diperlukan kerjasama dan kolaborasi antar stakeholder terkait. Hal ini seiring dengan persoalan keluarga yang sifatnya multidimensi sehingga program-program pembangunan di Kabupaten Bandung terutama yang terkait dengan pembangunan keluarga perlu disinergikan. Setiap keluarga perlu memperkokoh ikatan dalam keluarga sehingga masing-masing peran dalam rumah tangga dapat dijalankan dengan baik dan harmonis. Selain itu, penggalian dan optimalisasi potensi keluarga juga perlu dilakukan agar dapat mewujudkan keluarga yang mandiri, Bahagia, dan sejahtera. 
p-ISSN: $2655-7304$

e-ISSN: 6655-8953

\section{DAFTAR PUSTAKA}

[1] DP3AKB Jabar. (2019). Ketahanan Kelurga. Diakses melalui: http://dp3akb.jabarprov.go.id/official/ketahanan-keluarga/

[2] Kemen PPPA RI. (2016). Buku Pembangunan Ketahanan Keluarga. Diakses melalui: https://www.kemenpppa.go.id/lib/uploads/list/9455b-buku-pembangunan-ketahanankeluarga-2016.pdf

[3] Notif.id. (2020). Akibat Wabah Covid-29 kasus KDRT dan kejahatan jalanan di Kabupaten Bandung meningkat. Diakses melalui: https://notif.id/2020/13420/news/regional/akibatwabah-covid-19-kasus-kdrt-dan-kejahatan-jalanan-di-kabupaten-bandung-meningkat/

[4] Peraturan Pemerintah Republik Indonesia Nomor 21 Tahun 1994 tentang Penyelenggaraan Pembangunan Keluarga Sejahtera.

[5] Peraturan Menteri Negara Pemberdayaan Perempuan dan Perlindungan Anak Nomor 6 Tahun 2013 tentang Pelaksanaan Pembangunan Keluarga.

[6] Radar Bandung. (2020). Ulah Virus Corona 995 pekerja di Kabupaten Bandung cipecat, 1850 dirumahkan. Diakses melalui: https:/www.radarbandung.id/ bandung-raya/kabupatenbandung-bandung-raya/2020/04/08/ulah-virus-corona-995- pekerja-di-kab-bandung-dipecat1-850-dirumahkan/

[7] Ristekdikti. (2016). Buku Ajar Mata Kuliah Wajib Umum Pendidikan Kewarganegaraan untuk Perguruan Tinggi. Jakarta: Direktorat Jenderal Pembelajaran dan Kemahasiswaan Kementerian Riset, Teknologi, dan Pendidikan Tinggi RI.

[8] Undang-Undang Nomor 1 Tahun 1974 tentang Perkawinan.

[9] Undang-Undang Nomor 23 Tahun 2002 tentang Perlindungan Anak.

[10] Undang-Undang Nomor 52 Tahun 2009 tentang Perkembangan Kependudukan dan Pembangunan Keluarga.

[11] Undang-undang No 35 tahun 2014 tentang Perubahan atas Undang-undang Nomor 23 Tahun 2002 tentang Perlindungan Anak.

[12] Suyanto, et all. (2015). Metode Penelitian Sosial Berbagai Alternatif Pendekatan Edisi Ketiga. Jakarta: Prenadamedia Group.

[13] Willis, S. (2014). Remaja dan Masalahnya Mengupas Berbagai Bentuk Kenakalan Remaja, Narkoba, Free Sex, dan Pemecahannya. Bandung: ALFABETA.

[14] Yudiyanto. (2016). Ketahanan Nasional Berbasis Kokohnya Keluarga Indonesia Memasuki Masyarakat Ekonomi Asean (MEA). Ri'ayah Jurnal Sosial dan Keagamaan Pascasarjana IAIN Metro, 01 (01), pp: 40-50. 